Đokić, M., Marković, B., Gantner, V., Marković, M. (2020): Association of genetic variants of $\beta$-lactoglobulin gene with milk traits of Jezeropivska sheep breed. Agriculture and Forestry, 66 (3): 15-23.

DOI: 10.17707/AgricultForest.66.3.02

\begin{abstract}
Milena ĐOKIĆ , Božidarka MARKOVIĆ $^{1}$, Vesna GANTNER ${ }^{2}$, Milan MARKOVIĆ ${ }^{1}$
\end{abstract}

\title{
ASSOCIATION OF GENETIC VARIANTS OF $\beta$-LACTOGLOBULIN GENE WITH MILK TRAITS OF JEZEROPIVSKA SHEEP BREED
}

\section{SUMMARY}

Association of genetic variants of $\beta$-lactoglobulin $(\beta-\mathrm{Lg})$ on milk traits of Montenegrin autochthonous sheep breed - Jezeropivska sheep was studied. Polymorphisms within ovine $\beta$-Lg genes were detected using PCR-RFLP method by RsaI restriction endonuclease. Milk yield and milk composition parameters during lactation were determined by using the standard ICAR procedures.

The obtained results showed a prevalence of A allele (0.625) compared to $\mathrm{B}$ allele (0.375), while the frequencies of genotypes were: 0.364 (AA), 0.523 $(\mathrm{AB})$ and 0.113 (BB). No statistically significant differences in duration of lactation and total milk yield between these three genotypes were found.

Daily milk yield was the highest $(0.70 \mathrm{~kg})$ in ewes with $\mathrm{BB}$ genotype $\beta$ lactoglobulin then $\mathrm{AB}$ genotype follows $(0.60 \mathrm{~kg})$ and $\mathrm{AA}(0.54 \mathrm{~kg})$ genotype. Genotype AA of Jezeropivska breed was linked with the higher protein content $(5.86 \%)$. The protein content in the milk of $\mathrm{AB}$ and $\mathrm{BB}$ genotype was the same (5.64\%). Significant association between $A B$ genotype of $\beta$-lactoglobulin gene with higher lactose content (4.67\%) was found.

The results presented in this study could be useful in improvement of the concept of conservation and sustainable use of this autochthonous sheep breed, while gene of $\beta-\mathrm{Lg}$ as a potential marker in improving milk traits of sheep.

Keywords: Jezeropivska sheep, milk yield, milk composition, $\beta$ lactoglobulin, genotype.

\section{INTRODUCTION}

Milk and dairy products from sheep represent a significant part of the agricultural economy worldwide, especially in marginal areas (Selvaggi et al., 2015). There is a strong association between milk protein polymorphisms and its yield, composition and technological aspects. Hence, in-depth research of genetic

\footnotetext{
${ }^{1}$ Milena Đokić, (corresponding author: milena.dj1405@gmail.com), Božidarka Marković, Milan Marković, University of Montenegro, Biotechnical Faculty Podgorica, MONTENEGRO.

${ }^{2}$ Vesna Gantner, Faculty of Agrobiotechnical Sciences Osijek, University of Josip Juraj Strossmayer in Osijek, CROATIA.

Paper presented at the GEA (Geo Eco-Eco Agro) International Conference 2020, Podgorica Notes: The authors declare that they have no conflicts of interest. Authorship Form signed online. 
polymorphisms of sheep milk proteins, especially considering the great genetic biodiversity of sheep breeds is necessary to be carried out. Milk proteins are very heterogeneous. Casein, as the main milk protein, constitutes approximately 75$80 \%$ of the total milk proteins, while whey proteins $20-25 \%$ (Davoodi et al., 2016). The whey proteins have a high nutritive value due to fact that they are a precious source of digestible proteins. The whey proteins account for $17-22 \%$ of total proteins in sheep milk. Whey obtained from sheep milk is particularly rich in $\beta$-lactoglobulin, but low in $\alpha$-lactalbumin content (Moatsou et al., 2005).

The genes for $\beta$-Lg protein are located on chromosome 3 with $4.9 \mathrm{~Kb}$ long transcription units containing 7 exons and 6 introns. There are three polymorphic genetic variants (A, B and C alleles) of sheep $\beta$ - $\mathrm{Lg}$ described until now (Amigo et al., 2000; Şahin et al., 2011; Rustempašić et al., 2018). The polymorphism is a consequence of the substitution of one nucleotide in exon II (T-C), which is expressed by a change in the amino acid at position 20 (Tir in His). $\beta-\mathrm{Lg}$ A has tyrosine while $\beta$-Lg B histidine (Prinzenberg and Erhardt, 1999; Amigo et al., 2000; El-Shazly et al., 2012; Özmen and Kul, 2016). The variant C is a subtype of ovine variant A with a single exchange of Arg-Gln at position 148. The C variant was described first in German Merino landsheep at a frequency of 0.175 and in Hungarian Merino crosses. In Spanish Merinos the $\mathrm{C}$ allele was found at low frequencies (0.013), (Prinzenberg and Erhardt, 1999; Amigo et al., 2000).

The $\beta$-Lg polymorphism was also studied to check its relationships with milk yield and milk composition. According to the recent investigations, genetic polymorphism of milk proteins $(\beta-\mathrm{Lg})$ in sheep has been closely associated with milk production parameters and technological properties (El-Shazly et al., 2012; Özmen and Kul, 2016; Wafaa et al., 2019). Mele et al. (2007) highlighted a codominant effect of beta-lactoglobulin alleles on the concentration of some milk fatty acids. In the other studies of ewe's $\beta$-Lg (Staiger et al. 2010, Kawecka and Radko, 2011) contradictory results have been obtained.

Montenegro has specific geographical characteristics and the climatic conditions not favourable for intensive growing of field crops - due to that animal husbandry was a major agricultural and economic activity in the past, especially sheep sector (Marković et al., 2007; Marković et al., 2011). Natural grasslands have a special importance in Montenegro, because their share in the total agricultural area is above $90 \%$ and they are often the only source of fodder for ruminants (Dubljević et al., 2020).

The sheep production is mainly based on rearing autochthonous breeds. Jezeropivska pramenka is one of the most important autochthonous Montenegrin sheep breeds, and made about $20 \%$ of its total sheep population. The breed is traditionally reared in mountain area of Durmitor and Sinjajevina, and partly in the central part of the country. Jezeropivska breed belongs to the Pramenka group of breeds with coarse wool and long tail. It is well adapted to extreme environmental conditions, especially to harsh mountain climates. Milk production capacity of Jezeropivska breed varies a lot, depending of rearing conditions. In the study of Marković et al. (2014), average milk yield was $94.1 \mathrm{~kg}$ with variation 
from $50 \mathrm{~kg}$ to $200 \mathrm{~kg}$, while average duration of lactation was 178.5 days. In the same study, the percentages of the main milk components were: $5.71 \%$ of fat, $5.57 \%$ of protein, $4.47 \%$ of lactose and $11.04 \%$ of solid non-fat. Similar to the other Montenegrin sheep breeds (Bardoka, Ljaba, Sora, Sjenička and Žuja) Jezeropivska pramenka is three-purpose breed, with meat and milk as the main products, while wool is low value by-product. In Montenegro sheep milk is generally used for manufacture of different traditional local product (cheeses, yogurt, kaymak - skorup, jardum etc.). Sheep's milk has high values of chemical components, and it is the best raw material for the production of cheese, because it gives twice higher randman than cow's milk (Jandrić and Savić, 2019). Sheep milk products are of excellent quality and high nutritional value, and therefore they are highly valued on the market (Marković et al., 2016).

Having in mind the importance of autochthonous breeds in generally, the aim of this research was to do genetic characterization of polymorphic forms of $\beta$-Lg genes in Jezeropivska pramenka sheep breed. Also, for obtaining complete data, it is important to investigate milk production traits (duration of lactation, milk yield and milk composition) and to analyse the effect of $\beta$-Lg genotypes on the milk properties of this autochthonous Montenegrin sheep breed what would be in line with similar research on other sheep breeds in Europe and in the world.

The obtained data of polymorphism of milk protein gene can be used as an important selection tool in the sheep breeding programs. Effective selection on favourable genotypes of milk proteins can increase the frequency of alleles with a positive effect on milk properties and milk quality.

\section{MATERIAL AND METHODS}

The study was conducted in a typical area of rearing Jezeropivska Pramenka breed, at the Žabljak plateau. The study was carried out on 44 ewes of Jezeropivska Pramenka sheep breed. Milk yield was recorded during lactation. Milk samples to examine the chemical composition of milk were collected, while blood samples were taken to determine $\beta$-lactoglobulin polymorphism.

Milk recording was performed in accordance with ICAR rules (AT method). The first milk recording was performed 20 to 30 days after lambing and consequently in regular monthly intervals to the end of the lactation period. In total, five recordings were performed during lactation. During each of milk recording, individual milk samples were collected in special plastic bottles $(50 \mathrm{ml})$.

The blood samples were collected from the jugular vein of milking ewes, using blood collection tube - vacutainers with EDTA, as an anticoagulant.

Analyses of the milk chemical components (fat, protein, lactose, non-fat dry matter - SNF) were performed using the Milk Scan 4000 instrument in the Dairy Laboratory of the Biotechnical Faculty in Podgorica. Isolation of DNA from blood samples and $\beta$-lactoglobulin genotyping were performed in the Laboratory of Molecular Genetic at the Biotechnical Faculty in Podgorica. 
DNA extraction: Genomic DNA was isolated from the blood samples using phenol-chloroform method (Ivanković and Dovč, 2004). The quality of DNA was checked by spectrophotometry and good quality DNA samples were used in genotyping.

PCR - RFLP of $\beta$-lg gene: $\beta$-Lactoglobulin genotypes were identified using procedure described by Ivanković and Dovč (2004) and Şahin et al. (2011). The amplification of a part genome DNA - genes for the synthesis of milk protein $\beta$ lactoglobulin (120 bp) was performed using a programmed Thermal Cycler (Eppendorf Mastercycler). The PCR amplifications were performed in reaction mixtures of $20 \mu \mathrm{L}$ containing $10 \mu \mathrm{L}$ of PCR Master Mix, $1,1 \mu \mathrm{L}$ of each primer, $5,8 \mu \mathrm{L} \mathrm{H}_{2} \mathrm{O}$ and $2 \mu \mathrm{L}$ genomic DNA. Thermal Cycler was programmed for an initial denaturation at $95^{\circ} \mathrm{C}$ for $3 \mathrm{~min}$, followed by 35 cycles each with denaturing at $93^{\circ} \mathrm{C}$ for $15 \mathrm{~s}$, annealing at $58^{\circ} \mathrm{C}$ for $15 \mathrm{~s}$, extension at $72^{\circ} \mathrm{C}$ for $2 \mathrm{~s}$, and a final extension at $72^{\circ} \mathrm{C}$ for $2 \mathrm{~min}$. The restriction fragments were directly analyzed by electrophoresis in $1 \%$ agarose gels in $1 \times \mathrm{TAE}$ buffer, stained with ethidium bromide and visualized under UV light. The genotypes of the analyzed individuals at the $\beta$-lactoglobulin locus were determined using the restriction fragments observed in the gel.

Table 1. The Primer sequences for $\beta$-lactoglobulin variants

\begin{tabular}{|r|c|c|}
\hline Primer $\boldsymbol{\beta}-\mathbf{L g}$ & Primer Sequences & Restriction Enzymes \\
\cline { 1 - 2 } BLG1 & 5'CAACTCAAGGTCCCTCTCCA3' & \multirow{2}{*}{ Rsal } \\
\hline BLG2 & 5'CTTCAGCTCCTCCACGTACA3' & \\
\hline
\end{tabular}

A total volume of $15 \mu \mathrm{L}$ of each PCR product was digested with $10 \mu \mathrm{L}$ of RsaI endonuclease restriction enzymes for 3 hours at $37^{\circ} \mathrm{C}$. Digested products were analyzed by means of electrophoresis in 3\% agarose gel stained with ethidium bromide. The digested products were visualized and documented.

Statistical analysis: The data processing was performed using the statistical program Statistica (version 10). The frequencies of alleles and $\beta$-lactoglobulin genotypes were determined by the goodness test of fit to HWE (Hardy Weinberg Equilibrium).

\section{RESULTS AND DISCUSSION}

Restriction fragment length polymorphism was evidenced after digestion with RsaI endonuclease. Allele discrimination was based on size differentiation (bp) of $\beta$ - $\mathrm{Lg}$ and three different genotypes of Jezeropivska pramenka breed: AA (66, 37 and $17 \mathrm{bp}), \mathrm{AB}(103,66,37$ and $17 \mathrm{bp})$ and $\mathrm{BB}$ (103 and 17 base pairs) were detected.

The results of genetic characterization (Table 2) showed high domination of allele A with frequency of 0.625 in comparison to allele B with frequency of 0.375. Regarding genotypes, the highest frequency was identified for $\mathrm{AB}$ genotype (0.523), then for AA genotype (0.364) and the lowest for BB genotype (0.113). 
The occurrence of $\beta$ - $\mathrm{Lg}$ variants in this study is similar to the other sheep breeds studied so far. According to the research of Ivanković and Dovč (2004), Kusza et al. (2014), El-Shazly et al. (2012) and Marković et al. (2015) A and B alleles of $\beta-\mathrm{Lg}$ were widely reported in almost all examined sheep breeds. Similar to our results for Jezeropivska pramenka breed, the higher frequencies of allele A of $\beta$-Lg were reported by Amigo et al. (2000) for Barbaresca-Siciliana, Lacaune, Tsigaja and Massese breeds, Wafaa et al. (2019) for Awassi breed, as well as Amigo et al. (2000) for many West European sheep breeds (Blackfaced, Border Leicester Merino, Cheviot, Dorset Horn, Delle Langhe, East Friesian, Finnish Landrace, Manchega, Massese, Merino, Merinoland, Segurena, Suffolk, Welsh). The highest frequency of allele A in Turkish sheep breeds was detected in Tuj breed as 0.7188 (Şahin et al., 2011).

Table 2. Frequency of genes and genotypes for $\beta$-lactoglobulin of Jezeropivska pramenka $(\mathrm{n}=44)$

\begin{tabular}{|c|c|c|c|c|}
\hline $\boldsymbol{\beta}$-lactoglobulin & & Ho & He & Frequency \\
\hline \multirow{3}{*}{ Alleles } & A & 55 & 55.01 & 0.625 \\
\cline { 2 - 5 } & B & 33 & 33.21 & 0.375 \\
\hline \multirow{3}{*}{ Genotype } & AA & 16 & 17,19 & 0.364 \\
\cline { 2 - 5 } & AB & 23 & 20.63 & 0.523 \\
\cline { 2 - 5 } & BB & 5 & 6.29 & 0.113 \\
\hline
\end{tabular}

The allele and genotypes frequencies of $\beta$-lactoglobulin in Pramenka breed sheep in Bosnia and Herzegovina, which belong to the same group as Jezeropivska breed (group of Pramenka breeds) are very similar to ours. Rustempašić et al. (2018) reported that allele frequency was 0.547 and 0.453 , A and $\mathrm{B}$ respectively, while genotype frequencies were: AA (0.325), AB (0.445), and BB (0.229). However, the results of Masala et al. (2020) for Dupska Pramenka breed in Bosnia and Herzegovina were shown higher frequency of B genetic variation (0.52) than $\mathrm{A}(0.48)$, while the most common genotype was the $\mathrm{AB}$ determined in $68 \%$ of the examined population.

The opposite to our results, Amigo et al. (2000) reported domination of allele B for Carranzana, Chios, Lacha, Sarda, Tajik, Valle del Belice breeds, as well as El-Shazly et al. (2012) for Noemi and Sawakni breeds.

The higher frequency of $\mathrm{AB}$ genotype, similar to ours, was obtained for many autochthonous breeds: Croatian Pag breed ewes (Čubrić-Čurik et al. 2002); Greek Chios breeds (Triantaphyllopoulos et al. 2017); native Turkish fat-tailed sheep breeds - Akkaraman, Awassi, Tuj, Karakaş, Norduz, Güney Karaman and Kangal (Şahin et al. 2011) and in three Hungarian sheep breeds - Cokanski, Rusty Tsigai and Zomborski Tsigai (Kusza et al. 2014).

The average values with standard deviation of milk production traits (lactation duration, total milk yield, daily milk yield) for the three $\beta$-Lg genotype are presented in Table 3. 
The lactation duration of Jezeropivska pramenka breed varied in the narrow range, from 173.19 days of $\mathrm{AB}$ genotype to the 177.23 days of $\mathrm{AA}$ genotype, and differences among genotypes were not significant $(\mathrm{P}>0.05)$. The total milk yield was lowest in AA genotype $(96.34 \mathrm{~kg})$ and highest in BB genotype $(109.09 \mathrm{~kg})$, but the differences between them were not significant $(\mathrm{P}>0.05)$. From the other side, the obtained results show significant differences $(\mathrm{P}<0.05)$ in daily milk yield, where ewes with $\mathrm{BB}$ genotype had the highest daily yield $(0.70 \mathrm{~kg})$, followed by $\mathrm{AB}$ genotype $(0.60 \mathrm{~kg})$, while AA genotype had lowest $(0.54 \mathrm{~kg})$.

Table 3. Association of $\beta$ - $\mathrm{Lg}$ genotypes with milk production traits of Jezeropivska pramenka sheep breed

\begin{tabular}{|l|c|c|c|}
\hline \multirow{2}{*}{ Milk traits } & \multicolumn{3}{|c|}{ B-Lg genotype } \\
\cline { 2 - 4 } & $\mathbf{A A}$ & $\mathbf{A B}$ & BB \\
\hline & $\bar{X} \pm \mathrm{SD}$ & $\bar{X} \pm \mathrm{SD}$ & $\bar{X} \pm \mathrm{SD}$ \\
Lactation duration, days & $177 \pm 23.13$ & $173 \pm 19.59$ & $173 \pm 25.46$ \\
\hline Total milk yield, $\mathrm{kg}$ & $96.34 \pm 18.21$ & $102.25 \pm 36.42$ & $109.09 \pm 54.27$ \\
\hline Daily milk yield, $\mathrm{kg}$ & $0.54^{\mathrm{a}} \pm 0.21$ & $0.60^{\mathrm{ab}} \pm 0.33$ & $0.70^{\mathrm{b}} \pm 0.49$ \\
\hline
\end{tabular}

The average values with different letters in the superscript indicate significant differences between $\beta$ - $\mathrm{Lg}$ genotypes $(\mathrm{P}<0.05)$.

The results of our research related to the association of $\beta$ - $L g$ polymorphism with milk performance in sheep indicate the superiority of $\mathrm{BB}$ to the other genotypes (AA and $\mathrm{AB}$ ) in milk yield, without statistically significant differences among these genotypes. The similar relations among genotypes were obtained for Polish Merino (Kawecka and Radko, 2011) and of East Friesian dairy sheep (Staiger et al., 2010).

Regarding milk composition, the highest fat and protein content $(4.91 \%$ and 5.86\%) were of AA genotype, while the lowest (4.65\% and 5.64\%) obtained for $\mathrm{AB}$ genotype. The significant differences identified between $\mathrm{AA}$ and the other two genotypes only for protein content $(\mathrm{P}<0.05)$, Table 4 .

Table 4. Association of $\beta-\mathrm{Lg}$ genotypes with milk composition traits in Jezeropivska pramenka sheep breed

\begin{tabular}{|l|c|c|c|}
\hline \multirow{2}{*}{ Milk composition } & \multicolumn{3}{|c|}{ B-Lg genotype } \\
\cline { 2 - 4 } & $\mathbf{A A}$ & $\mathbf{A B}$ & BB \\
\hline & $\bar{X} \pm \mathrm{SD}$ & $\bar{X} \pm \mathrm{SD}$ & $\bar{X} \pm \mathrm{SD}$ \\
\hline Fat \% & $4.91 \pm 2.53$ & $4.65 \pm 1.83$ & $4.84 \pm 2.23$ \\
\hline Protein \% & $5.86^{\mathrm{a}} \pm 1.29$ & $5.64^{\mathrm{b}} \pm 0.92$ & $5.64^{\mathrm{b}} \pm 0.90$ \\
\hline Lactose \% & $4.55^{\mathrm{a}} \pm 0.65$ & $4.67^{\mathrm{b}} \pm 0.54$ & $4.61^{\mathrm{ab}} \pm 0.60$ \\
\hline SNF \% & $11.14 \pm 1.71$ & $11.21 \pm 0.94$ & $11.14 \pm 0.68$ \\
\hline
\end{tabular}

The averages with different letters indicate significance of differences between $\beta$-Lg genotypes $(\mathrm{P}<0.05)$; SNF- solid non fat. 
No statistically significant differences were found in milk fat content between genotypes in the studied sheep. The opposite to the fat and protein results, the lactose content was significantly lower in AA genotype $(4.55 \%)$ than in $\mathrm{AB}$ genotype $(4.67 \%)$, while content of lactose in BB genotype was in the middle $(4.61 \%)$. Regarding SNF content, there were no significant differences between genotypes, the results ranged from $11.14 \%$ in $\mathrm{AA}$ and $\mathrm{BB}$ genotype to $11.21 \%$ in $\mathrm{AB}$ genotype.

Our results of association of $\beta$-Lg genotypes and protein and lactose content in milk are in accordance with results of Kusza et al. (2014) revealed for different dairy breeds, but not fully with the results reported by Triantaphyllopoulos et al. (2017), who found that AA genotype of $\beta$ - $\mathrm{Lg}$ gene of Chios and Karagouniko breeds was associated with the highest fat, protein percentage, while greater lactose percentage observed in genotype $\mathrm{AB}-5,42 \%$ compared to genotype $\mathrm{AA}$ $4.96 \%$ and to genotype BB $-5.32 \%$.

The results of investigation of Özmen and Kul (2016) on allele and genotype effects on milk production traits Sakiz and Awassi breeds are fully in accordance with our results. They obtained that ewes of AB genotype had a greater milk yield than those with AA genotype, while homozygous AA ewes had higher milk protein and fat percentage when compared with other two genotypes.

\section{CONCLUSIONS}

This study shows that Jezeropivska sheep breed has a genetic variability in the $\beta$-lactoglobulin locus. A significant association of $\beta$-Lg genotypes and daily milk yield and milk quality was revealed. Although, the results showed that milk yield did not have a clear relationship with $\beta$-LG genotype, protein and lactose content were statistical significant. More investigation of the effect of $\beta-\mathrm{Lg}$ polymorphism and milk composition is needed. It was determined that milk protein polymorphism can be considered as a potential tool in the breeding program of Jezeropivska sheep breed, especially regarding selection of genotypes associated with better milk composition. This research is also the important contribution for creation of long-term conservation strategy of the autochthonous sheep breeds in Montenegro.

\section{REFERENCES}

Amigo, L., Recio, I., Ramos, M. (2000): Genetic polymorphism of ovine milk proteins: its influence on technological properties of milk- a review. International Dairy Journal 10, 135-149.

Čubrić-Čurik, V., Feligini, M., Lukac-Havranek, J., Curik, I., Guiseppe, E. (2002): Genetic polymorphism of $\beta$-lactoglobulin in native sheep from the Island of Pag. Food Technol Biotechnol. 40: 75-78.

Davoodi, S. H., Shahbazi, R., Esmaeili, S., Sohrabvandi, S., Mortazavian, A.M., Jazayeri, S. and Davoodi, A.T. (2016): "Health-Related Aspects of Milk Proteins." Iranian journal of pharmaceutical research : IJPR vol. 15,3 (2016): 573-591. 
Dubljević, R., Radonjić, D., Marković, M. (2020): Production traits of major types of grasslands in the Durmitor area. Agriculture and Forestry, 66 (2): 229-236

El-Shazly, S.A., Mahfouz, M.E., Al-Otaibi, S.A., and Ahmed, M.M. (2012): Genetic polymorphism in $\beta$-lactoglobulin gene of some sheep breeds in the Kingdom of Saudi Arabia (KSA) and its influence on milk composition. African Journal of Biotechnology Vol. 11(19), 4330-4337.

Ivanković, A. and Dovč, P. (2004): Polimorfizem genov za $\beta$-laktoglobulin in $\alpha$ s1-kazein paske ovce, Acta agriculturae slovenica, 842, 121- 130.

Jandrić, M., Savić, Z. (2019): Influence of milk on the content and changes of milk fat during production of sjenički white cheese. Agriculture and Forestry, 65 (4): 175182. DOI:10.17707/AgricultForest.65.4.15

Kawecka, A and Radko, A. (2011): Genetic polymorphism of $\beta$-lactoglobulin in sheep raised for milk production. Journal of Applied Animal Research, Vol. 39, No. 1., 68-71.

Kusza, S., Sziszkosz, N., Nagy, K., Masala, A., Kukovics, S. and András, J. (2014): Preliminary result of a genetic polymorphism of $\beta$-lactoglobulin gene and the phylogenetic study of ten balkan and central european indigenous sheep breeds. Biohimica polonica. Vol. 62, No 1/2015, 109-112.

Marković, B., Đokić, M., Kostić, S., Marković, M. (2016): Stanje i trendovi ovčarske proizvodnja na durmitorskom području, CANU, Podgorica.

Marković, B., Ivanković, A., Mirecki, S, Marković, M. (2015): Genetic polymorphism of beta - lactoglobulin in the three sheep breeds in Montenegro. International symposium on Animal Science, Novi Sad, Serbia. 159-164.

Marković, B., Marković, M., Adzić, N. (2007): The farm animal genetic resources of Montenegro, Biotechnology in Animal Husbandry 23 (3-4) ISSN 1450-9156, Institute for Animal Husbandry, Belgrade-Zemun, 1-9.

Marković, B., Marković, M., Mirecki, S., Radonjić D., (2014): Variation of milk yield and milk composition of Pivska pramenka sheep breed through lactation, Proceedings of the International Symposium on Animal Science, BeogradZemun, 167-173.

Marković, B., Marković, M., Radonjić, D., Veljić, M. (2011): Sustainable sheep and goat production based on the local breeds in Montenegro. 8th Global Conference on Consevation on Animal Genetic Resources. Tekirdag Turkiye. 414-420.

Masala, A., Alilović, I., Ohran, H., Kusza, S., Goletic, T., Hrkovic-Porobija, A., HodzicGenetic, A. (2020): Polymorphism $\beta$-Lactoglobulin Gene in Dubska Pramenka Sheep Breed. CMBEBIH 2019, 641-645.

Mele, M., Conte, G., Serra, A., Buccioni, A., Secchiari, P. (2007): Relationship between beta-lactoglobulin polymorphism and milk fatty acid composition in milk of Massese dairy ewes. Small Ruminant Research 73, 37-44.

Moatsou, G., Hatzinaki, A., Samolada, M., Anifantakis, E. (2005). Major whey proteins in ovine and caprine acid wheys from indigenous Greek breeds. Int. Dairy J. 15: $123-131$.

Özmen, O., Kul, S. (2016): Investigating the genetic polymorphism in the exon 2 region of ovine beta-lactoglobulin gene and its association with some milk traits. Ankara Üniv Vet Fak Derg, 63, 323-328.

Prinzenberg, M. and Erhardt, G. (1999): Molecular genetic characterization of ovine blactoglobulin C allele and detection by PCR-RFLP. J. Anim. Breed. Genet. 116, 9-14. 
Rustempašić, A., Dokso, A., Zečević, E., Hodžić, A., Hrković-Porobija, A., Sarić, Z., Miskoska-Milevska, E., Popovski, Z. and Brka, M. (2018): Polymorphism of $\beta$ lactoglobulin in Pramenka sheep breed in Bosnia and Herzegovina.

Şahin, E., Karsli, T., Elmaci, C., Balcioğlu, M.S. (2011): Beta-Lactoglobulin Gene Types in Turkish Fat-Tailed Sheep Breeds. Short communication. Kafkas Univ Vet Fak Derg 17 (6): 1031-1033.

Selvaggi, M., Laudadio, V., Dario, C., Tufarelli, V. (2015): $\beta$-lactoglobulin gene polymorphisms in sheep and effects on milk production traits: A review. Adv. Anim. Vet. Sci. 3(9): 478-484.

Staiger, E. A., Thonney, M. L., Buchanan, J. W., Rogers, E. R., Oltenacu, P. A. and Mateescu, R.G. (2010): Effect of prolactin, $\beta$-lactoglobulin, and $\kappa$-casein genotype on milk yield in East Friesian sheep. American Dairy Science Association. J. Dairy Sci. 93, 1736-1742.

Triantaphyllopoulos, K.A., Koutsouli, P., Kandris, A., Papachristou, D., Markopoulou, K.E., Mataragka, A., Massouras, T., Bizelis, I. (2017): Effect of ßlactoglobulin gene polymorphism, lactation stage and breed on milk traits in Chios and Karagouniko sheep breeds, Annals of Animal Science, DOI: 10.1515/aoas-20160058 .

Wafaa, I. I., Hassooni, H. A. and Alkhazraji, W. J. (2019): Association of $\beta$-lactoglobulin gene polymorphism with milk production and composition in local Awassi sheep. Plant Archives Vol. 19, Supplement 2, ISSN:0972-521 